\title{
A NOTE OF THANKS
}

We received the following communication from a friend:

While outwardly my colleagues were unchanged, a certain squint of eye, a certain tiredness betrayed the fact that inwardly they had been consumed.

The day was Thursday, November the Eleventh. The place was Boston. A hotel corridor, in disarray. Part of which disorder was my colleagues Lynn Boatner, Elton Kaufmann and Leroy Chang. The origin of their distress was obvious - they had just finished their year as program cochairmen.

The telephone rang. The clamor was scarcely noticeable in the tumult of that hallway, and yet tiredly one of them - I forget which; they seemed to have taken on a multiple personality picked up the receiver and muttered reassurances to an unknown symposium chairman. The others nodded absently, silently mouthing the advice the speaker was conveying.

"Excuse me, Lynn," I said hesitantly, extending my hand to the one of them I knew best. I meant to congratulate him on an excellent meeting. I imagined he had worked hard to help make it a success, and I wanted him to know I appreciated it.

"Oh,hi!" he said gamely, extending his own limp hand. He began at once to radiate confident leadership. Like Christmas tree bulbs his companions blinked on. They stood up, smiling. They accepted my praise like a familiar overcoat, one to which they were accustomed. They looked immediately beyond it, to what I was really after. They suspected I was about to let them down. Or already had, more likely.

To fail to fulfill that small obligation I had undertaken at their behest. It was written all over them. They had given me something to do, but they couldn't remember what. Not that it mattered; the meeting was over. Still, they had a certain restiveness that had been absent before I came. I felt guilty. It was an emotion they had evidently much inspired of late.

It made them begin to relax. They remembered it was over. They exchanged a smile.

It was Kaufmann who, soft as a conspirator, said, "It was a wonderful experience." The other two nodded. I didn't answer him. I was trying to draw him out. It didn't take long. "See, this guy at the lab said he would help me out. But ..."

Language failed him. He conveyed by gesture an attitude I was quick to apprehend. It doesn't bear mention. You are surely familiar with it.

Chang chimed in. "We had some disappointments," he said.

My colleagues sat silently for a moment. A few straggling scientists came by to offer their congratulations. My friends switched on each time, then comfortably off again.

"An awful lot of work got done here," one of the three observed. He extended his arm to embrace, not the three, but the rest of us. We all nodded.

"It's been very satisfying," Boatner mused. "It's very gratifying to organize something as complex as this and then, with the help of almost countless other people, be able to pull it off."

Kaufmann said, "The symposia chairmen; since you're writing this down, we ought to give them a plug."

My friend Lynn Boatner smiled wanly. "This is a once-in-a-lifetime experience." "You can say that again," said the others.

How extraordinary! I reflected as I flew home from Boston, that my colleagues would take themselves away from their labs and their own research, and for no reward but a stronger profession. We ought to do something to recognize these fellows for all their work, but I don't know exactly what it might be.

Perhaps you can think of something.

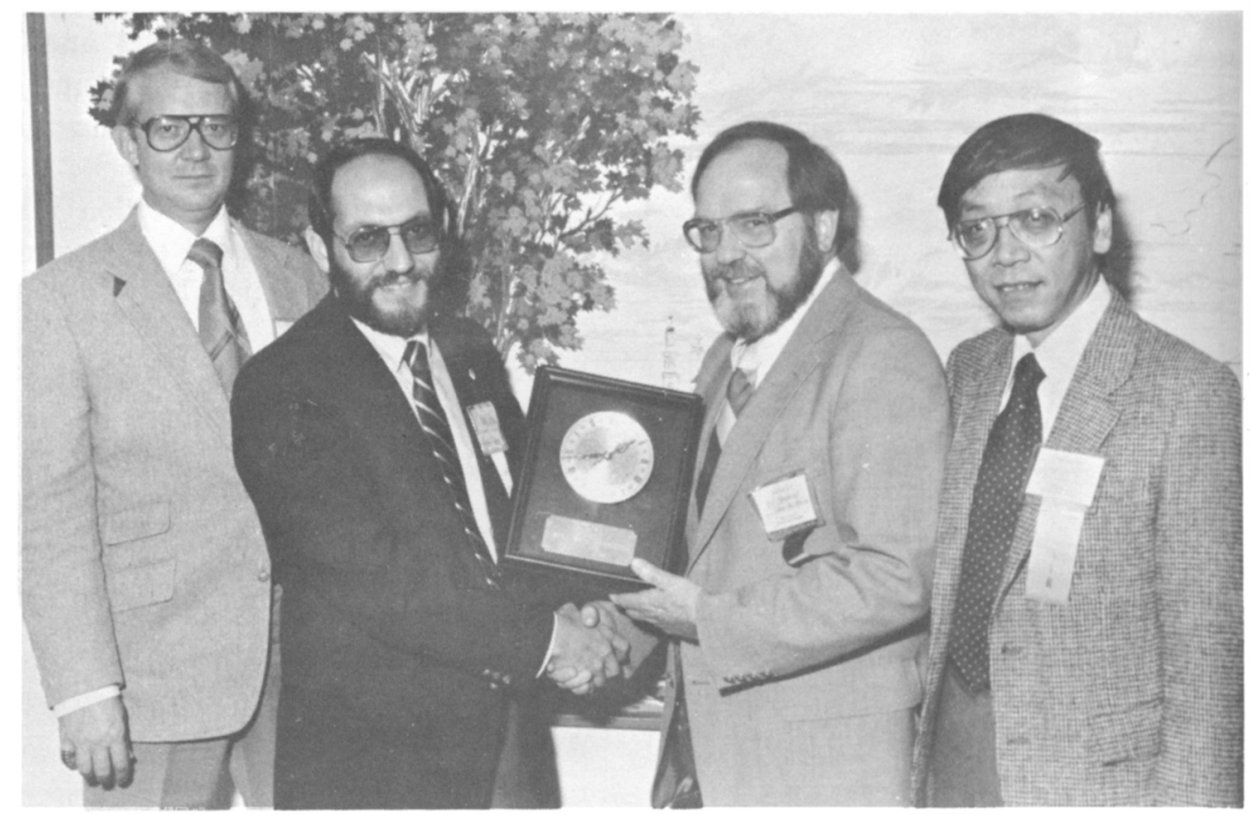

1982 PROGRAM CO-CHAIRMEN Lynn Boatner (left), Elton Kaufmann (dark jacket) and Leroy Chang (right) present University of New Mexico Professor Doug Brookins with a token of their appreciation - a clock that runs backward, so the time remaining before deadlines appears to increase. of fifteen months, the people rarely heard from begin to stand out,' Kaufmann said. 'Of course the fear is there that their silence means nothing is being done - but in Doug's case he simply didn't need our help to meet all the deadlines and produce an excellent meeting.' Brookins chaired the symposium on radwaste management. 